\title{
SCAI/AATS/ACC/STS operator and institutional requirements for transcatheter valve repair and replacement. Part II. Mitral valve
}

\author{
Carl L. Tommaso, MD, ${ }^{\mathrm{a}}$ David A. Fullerton, MD, ${ }^{\mathrm{b}}$ Ted Feldman, MD, FESC, FACC, FSCAI, \\ Larry S. Dean, MD, FSCAI, FACC, FAHA, ${ }^{d}$ Ziyad M. Hijazi, MD, MPH, FSCAI, FACC, FAAP, \\ Eric Horlick, MDCM, FRCPC, FSCAI, ${ }^{\mathrm{f}}$ Bonnie H. Weiner, MD, MSEC, MBA, ${ }^{\mathrm{g}}$ \\ Evan Zahn, MD, FACC, FSCAI, ${ }^{\mathrm{h}}$ Joaquin E. Cigarroa, MD, FACC, ${ }^{\mathrm{i}}$ Carlos E. Ruiz, MD, PhD, \\ Joseph Bavaria, MD, ${ }^{\mathrm{k}}$ Michael J. Mack, MD, ${ }^{1}$ Duke E. Cameron, MD ${ }^{\mathrm{m}}$ R. Morton Bolman III, MD, \\ D. Craig Miller, MD, ${ }^{\circ}$ Marc R. Moon, MD ${ }^{\mathrm{p}}$ Debabrata Mukherjee, MD, FACC, ${ }^{\mathrm{q}}$ Alfredo Trento, MD, \\ Gabriel S. Aldea, MD, and Emile A. Bacha, MD
}

\section{PREAMBLE}

The granting of staff privileges to physicians is an important mechanism to ensure quality care. The Joint Commission requires that medical staff privileges be based on professional criteria specified in medical staff bylaws. Physicians are charged with defining the criteria that constitute professional competence and with evaluating their peers accordingly. With the evolution of transcatheter valve therapy, an important opportunity arises for both cardiologists and surgeons to come together to identify the criteria for performing these procedures. The Society for Cardiovascular Angiography and Interventions (SCAI), American Association for Thoracic Surgery (AATS), American College of Cardiology (ACC), and The Society for Thoracic Surgeons (STS) have therefore joined together to provide recommendations for institutions to assess their potential for instituting and/or maintaining a transcatheter valve program. Since transcatheter valve therapy is in its infancy, there are few data upon which to base these recommendations. Therefore, many are based on expert consensus. As the procedures evolve, technology changes, experience grows, and more data accumulate, there will certainly be a need to update these recommendations. However, with the FDA having just approved these devices, the writing committee and participating societies believe that the recommendations listed in this report serve as an appropriate starting point. Since there is a strong consensus

From the Cardiac Cath Lab, ${ }^{a}$ North Shore Cardiologists, North Shore University Health System, Skokie, Ill; Cardiothoracic Surgery, ${ }^{\text {b }}$ University of Colorado Denver, Aurora, Colo; Cardiac Catheterization Laboratory, ${ }^{\mathrm{c}}$ Evanston Hospital, Evanston, and Cardiology Division, Walgreen Building 3rd Floor, Evanston, Ill; University of Washington School of Medicine, ${ }^{\mathrm{d}}$ Seattle, and UW Medicine Regional Heart Center, Seattle, Wash; Rush Center for Congenital \& Structural Heart Disease, ${ }^{\mathrm{e}}$ Chicago, and Pediatric Cardiology, Rush University Medical Center, Chicago, Ill; Peter Munk Cardiac Centre, ${ }^{f}$ Toronto General Hospital, Toronto, Ontario, Canada; Saint Vincent Hospital at Worcester Medical Center/ Fallon Clinic, ${ }^{\mathrm{g}}$ Worcester, and Boston Biomedical Associates, Northborough, Mass; Cedars-Sinai Medical Center, ${ }^{\mathrm{h}}$ Los Angeles, Calif; Department of Medicine, ${ }^{\mathrm{i}}$ Portland, Ore; Lenox Hill Heart and Vascular Institute of New York, ${ }^{\mathrm{j}}$ New York, NY; Division of Cardiothoracic Surgery, ${ }^{\mathrm{k}}$ Hospital of the University of Pennsylvania, Philadelphia, Pa; Cardiovascular Council Dallas, ${ }^{1}$ Heart Hospital Baylor Plano, Plano, Tex; The Dana and Albert "Cubby" Broccoli Center for Aortic Diseases, ${ }^{\mathrm{m}}$ The Johns Hopkins Hospital, Baltimore, Md; Division of Cardiac Surgery, ${ }^{\mathrm{n}}$ Harvard Medical School, Boston, Mass; Cardiovascular Surgical Physiology Research Laboratories, ${ }^{\circ}$ Stanford University Medical Center, Stanford, and Cardiovascular Surgery, Falk CV Research Center, Stanford, Calif; Division of that these new valve therapies are best performed using a team approach, these credentialing criteria may be best applied at the institutional level.

Partnering societies used the ACC's policy on relationships with industry to author this document. ${ }^{1}$ To avoid actual, potential, or perceived conflicts of interest that could arise as a result of industry relationships with or personal interests of the writing committee, all members of the writing committee, as well as peer reviewers of the document, were asked to disclose all current healthcare-related relationships, including those existing 12 months before initiation of the writing effort. A committee of interventional cardiologists and surgeons was formed to include a majority of members with no relevant relationships with industry (RWI) or other entities, and was led by an interventional cardiology chair and a surgical co-chair with no relevant RWI. Authors with relevant RWI were not permitted to draft or vote on content or recommendations pertaining to their RWI. RWI were reviewed on all conference calls and updated as changes occurred. Author and peer reviewer RWI pertinent to this document are disclosed in Appendices 1 and 2, respectively. The work of the writing committee was supported exclusively by the partnering societies without commercial support. Writing committee members volunteered their time for this effort. Conference calls of the writing committee were confidential and attended only by committee members.

Cardiothoracic Surgery, ${ }^{\mathrm{p}}$ Washington University, St. Louis, Mo; Cardiovascular Medicine, ${ }^{\mathrm{q}}$ Department of Internal Medicine, Texas Tech University, El Paso, Tex; Division of Cardiothoracic Surgery, ${ }^{\mathrm{r}}$ Cedar Sinai Medical Center, Los Angeles, Calif; Regional Heart Center, ${ }^{\mathrm{s}}$ University of Washington Medical Center, Seattle, Wash; and Division of Cardiac, Thoracic, and Vascular Surgery, New York Presbyterian/Columbia University Medical Center, New York, and Pediatric Cardiac Surgery, Morgan Stanley Children's Hospital of New York, New York, NY.

Received for publication May 6, 2014; accepted for publication May 6, 2014

Address for reprints: Carl L. Tommaso, MD, Skokie Hospital, NorthShore University Health System, 9669 N Kenton Ave, Skokie, IL 60076 (E-mail: ctommaso@ northshore.org)

J Thorac Cardiovasc Surg 2014;148:387-400

$0022-5223 / \$ 36.00$

Copyright (C) 2014 by The American Association for Thoracic Surgery, the American College of Cardiology Foundation, and the American Heart Association.

http://dx.doi.org/10.1016/j.jtcvs.2014.06.014 
SCAI, AATS, ACC, and STS believe that adherence to these recommendations will maximize the chances that these therapies will become a successful part of the armamentarium for treating valvular heart disease in the United States. In addition, these recommendations will hopefully facilitate optimum quality during the delivery of this therapy, which will be important to the development and implementation of future, less invasive approaches to structural heart disease.

\section{INTRODUCTION}

Fueled by the development of new technologies, treatment of valvular heart disease by transcatheter techniques has become part of the armamentarium of cardiac providers, enabling less invasive treatment for patients previously treatable only with open-heart surgery or, in many cases, not treatable at all. Recognition from the medical community of the applicability, effectiveness, and practicality of catheter-based transcatheter valve therapies has further increased interest in these treatments. Training program content, standards, credentialing, and board certifications for cardiac surgical procedures and percutaneous coronary intervention are well developed, but there is no such structure in the field of percutaneous structural or valvular heart disease therapies. The purpose of this article is to outline criteria for operator and institutional requirements, to enable institutions and providers to participate responsibly in this new and rapidly developing field.

The emergence of transcatheter valve repair and implantation has been facilitated by innovative devices, rapidly developing techniques, and careful patient selection. The combination of interventional skills, equipment, collaborative clinical management, surgical approaches, techniques, and decision-making distinguish the qualifications to participate in this field as unique, as does the complexity of the patients requiring these therapies. ${ }^{2,3}$ Given both the high-risk nature of these catheter interventions and the availability of established alternative treatment options using traditional surgical approaches, several considerations are important for institutions and operators planning to implement these new technologies.

Defining operator and institutional requirements for these novel therapies is an important first step to ensuring their optimal implementation.

Establishing a structural heart disease intervention therapy program requires several key components (Table 1). The defining principle is that this effort is a joint, institutionally based activity for cardiologists and cardiac surgeons. ${ }^{4}$ Thus, the specialty that provides some of these components will vary from program to program. A transcatheter valve therapy program that uses only one specialty is fundamentally deficient, and valve therapy programs should not be established without this multidisciplinary partnership. Comprehensive multidisciplinary teams (MDT) are, therefore, required for transcatheter valve therapies and structural interventional programs.

\section{KNOWLEDGE BASE AND SKILLS}

The critical cornerstone of a transcatheter valve program is a formal, collaborative effort between interventional cardiologists and cardiac surgeons. This element is essential to establishing a transcatheter valve program. No one individual, group, or specialty possesses all the necessary skills for the best patient outcomes. ${ }^{5}$ The overarching goal of these programs must be to provide the best possible patient-centered care. $^{6}$

Since these are new techniques, the correlation between operator experience and performance metrics for these procedures has yet to be established. The current pool of trained individuals is composed predominantly of those who have participated in industry-sponsored trials aimed at device approval. Therefore, the translation of currently available experiences with transcatheter valve therapies to the "real world" has yet to be evaluated in the United States.

Several core concepts should be implemented for all physicians performing these procedures, irrespective of their specialty background. ${ }^{7,8}$ They should all possess extensive knowledge of valvular heart disease, including the natural history of the disease, hemodynamics, appropriate diagnostics, optimal medical therapy, the application and outcome of invasive therapies, and procedural and perioperative care. ${ }^{9}$

The ability to interpret echocardiographic and other radiographic images (obtained at baseline, during the procedure and follow-up) is critical. Procedural echo guidance is critical to the procedural success and the procedural echocardiographer must be highly skilled. MDTs and procedural teams need to possess skills to acquire and interpret transthoracic and transesophageal studies. The use of 3D echocardiography is essential. Expertise in the interpretation of CT scans of the ilio-femoral vessels, cardiac anatomy, as well as aortic, mitral, and pulmonary valvular anatomy is critical for determining patient eligibility and the best approach and type of invasive procedure..$^{10,11}$

As noted, there is as yet no demonstrated direct correlation between operator experience with specific procedures and the skills necessary to perform transcatheter valve procedures. Furthermore, the specific skills required for each procedure are different. There are, however, some core concepts that professional societies have accepted as important for both facilities and operators. ${ }^{12,13}$ Minimum training for specific procedures and devices will, for the immediate future, be primarily dictated by FDA approval requirements. Simulation should play a significant role in technical training and proficiency maintenance for these evolving procedures. ${ }^{14-18}$ As the procedures become 
TABLE 1. Mitral valve institutional and operator requirements

\begin{tabular}{|c|c|}
\hline Institutional & 1000 Cath/400 PCI per year* \\
\hline \multirow[t]{2}{*}{ Interventionalist } & 50 Structural procedures per year (including ASD/PFO and trans-septal punctures) \\
\hline & Suitable training on devices to be used \\
\hline Surgical program & $\begin{array}{l}25 \text { Total mitral valve procedures per year, of which at least } 10 \text { must be mitral valve repairs } \dagger \\
\text { All cases must be submitted to a single national database }\end{array}$ \\
\hline \multirow[t]{2}{*}{ Existing programs } & 15 Mitral (total experience) \\
\hline & $\begin{array}{l}\text { Ongoing CME (or nursing/technologist equivalent) of } 10 \mathrm{~h} \text { per year of relevant material } \\
\text { All cases must be submitted to a single national database }\end{array}$ \\
\hline \multirow[t]{4}{*}{ New programs } & Because the indications are not defined, no volume criteria can be proposed yet \\
\hline & $\begin{array}{l}\text { Assuming approval would be for high-risk cohorts, } 10 \%-15 \% \text { mortality rate at } 30-\mathrm{d} \text {, similar to registry or published data } \\
65 \% 1-\mathrm{y} \text { survival rate }\end{array}$ \\
\hline & Ongoing CME (or nursing/technologist equivalent) of $10 \mathrm{~h}$ per year of relevant material \\
\hline & All cases must be submitted to a single national database \\
\hline Training & $\begin{array}{l}\text { Operator must be board certified in interventional cardiology or board certified/board eligible in pediatric cardiology or similar boards } \\
\text { from outside the United States. Cardiac surgeons must be board certified in thoracic surgery, or similar foreign equivalent. }\end{array}$ \\
\hline
\end{tabular}

integrated into mainstream care delivery, the strategy for training will likely need to be revised.

Minimum requirements for transcatheter valve therapies include an understanding of basic radiation safety necessary for optimal imaging, operator and patient exposure protection, and knowledge of the use of X-ray contrast agents, which may not be standard in cardiac surgery training and experience.

Training in the use of closed systems for hemodynamic monitoring and contrast injections will result in optimal integration into catheterization laboratories and hybrid environments. Catheter and wire skills, including knowledge of the use of various techniques and the equipment available to access complex anatomy and negotiate vascular and anatomic structures, are required. Understanding of the interplay of wires, catheters, and anatomy is required for completion of these procedures. These skills can be acquired in a variety of ways. Prior experience with a variety of interventional techniques is important. These include but are not limited to:

- Coronary diagnostic procedures

- Coronary interventions

- Peripheral vascular diagnostic procedures

- Peripheral vascular interventions

- Balloon aortic, mitral and pulmonic dilatation

- Stent implantation in right ventricle outflow tract and pulmonary arteries

- IABP and other cardiac support device placement, including initiation of percutaneous cardiopulmonary bypass

- pVAD placement

- EVAR or TEVAR procedures

- Transseptal techniques

- Coronary sinus access

- Large vessel access and closure
The experience of an interventionalist or surgeon should be relevant to the transcatheter valve procedure undertaken. For example, primary valve experience with aortic valve replacement should not be considered adequate experience for the performance of transcatheter mitral valve repair, because skill sets for one valve type do not necessarily translate to another valve type.

The application of sterile techniques, consistent with operating rooms standards, must be applied to these procedures and team members.

As one of the leaders of the team performing these procedures, the interventionalist must be able to enforce compliance with these standards. These procedures may involve open or partially open surgical components. Operating theater standards for sterile technique are therefore mandatory to ensure optimal patient outcomes.

\section{FACILITIES}

The institution should have an active valvular heart disease surgical program with at least two institutionally based cardiac surgeons experienced in valvular surgery, and should contain a full range of diagnostic imaging and therapeutic facilities, including:

1. Cardiac catheterization laboratory or hybrid operating room/cath lab equipped with a fixed radiographic imaging system with flat-panel fluoroscopy offering catheterization laboratory-quality imaging. A bi-plane unit may be advantageous, particularly for congenital heart disease.

2. Non-invasive imaging

a. Echocardiographic laboratory. Transthoracic and transesophageal echocardiographic capabilities with sonographers and echocardiographers experienced in valvular heart disease. Access to 3D echocardiography is necessary. 
b. Vascular laboratory (non-invasive) with vascular specialists capable of performing and interpreting vascular studies.

c. CT laboratory with CT technologists and specialists who can acquire and interpret cardiac CT studies.

3. Physical space-The implantation suite must have a sterile environment that meets operating room standards. Furthermore, it must have sufficient space to accommodate the necessary equipment for uncomplicated implantations as well as any additional equipment that may be necessary in the event of complications. Space for anesthesiology, echocardiography, and cardiopulmonary bypass equipment and personnel is essential. A specifically designed hybrid OR interventional suite is ideal; however, in the absence of such a facility, the interventional cardiac suite should have:

a. Circulating HVAC laminar flow diffusers (providing smooth, undisturbed air flow and usually placed directly over the procedure table) to meet air requirements for surgery rooms.

b. Asymmetrical/symmetrical 6-lamp $2 \times 4$ troffers (the inverted, usually metal trough suspended from the ceiling as a fixture for fluorescent lighting) to provide adequate high-output lighting for surgical interventions.

c. An adequate number of power receptacles that meet surgical equipment requirements.

d. For existing mitral valve procedures, cardiopulmonary bypass is almost never needed, but the room will likely be used for multiple types of structural procedures and with evolving techniques CPB may be more frequently necessary, thus adequate space to run the $\mathrm{CPB}$ machine in the interventional suite is desirable.

e. Gas outlets for the anesthesia machine.

f. An adequate room size to accommodate the standard equipment required in a cardiac catheterization laboratory (eg, $\mathrm{HD}$ displays and monitors, $\mathrm{O}_{2}$ analyzer, defibrillator/resuscitation cart, $\mathrm{O}_{2}$ supply, suction, compressed air, CO-oximeter, ACT analyzer).

4. Minimum room size of 800 square feet $\left(74.3 \mathrm{~m}^{2}\right)$ to accommodate echocardiographic equipment, sonographers, anesthesia equipment, the emergency CT surgical team, and cardiopulmonary bypass equipment (eg, surgeon, assistant, scrub tech, pump techs), if needed. Although in mitral cases, the need for emergent cardio-pulmonary bypass is minimal, the expectation is that this room will serve for other valvular procedures and the ability to convert to an $\mathrm{OR}$ is appropriate.

5. Equipment-The interventional suite should stock a large variety of interchangeable equipment, including various access kits, endovascular sheaths, and introducers ranging from $4 \mathrm{Fr}$ to $26 \mathrm{Fr}$ in various lengths, a wide range of guide wires for various purposes, cardiac diagnostic and interventional catheters, vascular closure devices, balloon dilatation catheters ranging from $2 \mathrm{~mm}$ to $30 \mathrm{~mm}$ in diameter and of various lengths and profiles, bare metal and covered stents (coronary and peripheral), occlusive vascular devices, snares and other retrieval devices, drainage catheters, and various implantable device sizes with their delivery systems.

6. Post-procedure intensive care facility with personnel experienced in managing patients who have undergone conventional open-heart valve procedures.

7. Use of a mobile $\mathrm{C}$-arm imaging system in an operating room is not adequate.

8. HYBRID OR - The Cath Lab Standards Document has outlined the specifications for a hybrid Cath Lab. ${ }^{19}$

Most importantly, there must be dedication on the part of the hospital to provide these services and support, both financially and with no time constraints on the personnel involved. A dedicated administrator as a member of the team is necessary.

\section{OTHER INSTITUTIONAL RESOURCES- FACILITIES, EQUIPMENT (DISPOSABLES AND CAPITAL EQUIPMENT), PERSONNEL, SUPPORT, AND COMMITMENT}

For pre- and post-procedure care and joint formal multidisciplinary patient consultation, adequate outpatient clinical care facilities are necessary. Appropriate office space for the medical, nursing, and technical personnel involved is also required, preferably in a central setting. Ancillary testing facilities (pulmonary function, echocardiography, vascular duplex scanning, clinical laboratory, MSCT) should be of high quality and be able to accommodate the patient load in a timely manner.

By their very nature, these complex procedures should only be performed in institutions that currently and routinely carry out relatively high volumes of surgical aortic, pulmonic, tricuspid, and mitral valve operations with established and verifiable track records of optimal surgical and interventional cardiology outcomes. Similarly, only institutions with interventional cardiology programs that have established and successful track records with balloon aortic and mitral valvuloplasty, catheter closure of periprosthetic valvular leaks, trans-septal procedures, insertion of atrial or ventricular septal closure devices, etc, should develop an integrated structural heart MDT.

The institutional commitment required for a successful program goes beyond the necessary space, personnel, and specialized facilities set forth above. The complex and time-consuming pre-procedure patient triage process 
and the amount and intensity of post-procedure patient care after discharge are labor intensive for the physicians, advanced practitioners (NP and PA), and nursing staff, as are informed consent and communication with patients, families, and referring providers. Heart Team decisionmaking conferences are valuable to patient care; therefore, future reimbursement models should take these conferences into consideration when developing policy. In addition to supporting the core nursing and technical support staff, arrangements between the institution and the physicians need to be in place to cover physician efforts dedicated to non-reimbursable hours of clinical care and medical management of the program.

The complexity of transcatheter valve procedures and the magnitude of institutional resources required are similar to established heart transplant and cardiac assist device programs, for which dedicated professionals, a minimum of infrastructure, a multidisciplinary team, RN/NP/PA, providers, coordinators, databases, and quality reporting are essential for optimal patient outcomes. This concept was endorsed by the Centers for Medicare and Medicaid Services through the establishment of certification criteria for the use of heart transplantation and cardiac assist devices in centers and, moreover, for eligibility for reimbursement of services provided. The same regulatory system was applied to professionals providing these services. Transcatheter valve treatment programs should undergo a similar regulatory process with CMS endorsement. Centers should be approved for specific transcatheter valve programs (aortic, mitral, and/or pulmonic) based on a minimum number of cases per year, and perioperative and 1-year outcomes above a minimum threshold.

Long-term outcome reporting is obligatory in order to track not only survival, but also parameters including periprocedural complications (eg, CVA, vascular, renal, infectious), mitral regurgitation (MR), the need for intervention, subsequent surgery, and quality of life. This type of reporting is essential because long-term outcome goals for these new procedures have not been established at this early stage. Development of a national data registry and participation by all institutions are mandatory.

\section{MULTIDISCIPLINARY TEAM}

The use of a team approach has been shown to improve outcomes in these types of complex procedures. ${ }^{20}$ The MDT necessary for an interventional valve therapy program involves far more than just a collaboration between the interventional cardiologist and cardiac surgeon. In addition to the individual physicians, components that extend to various departments are necessary. The idea that the MDT is composed of individual physicians working in a room performing the procedures is a superficial view that does not take into account the level of resources necessary for a successful valve therapy program. The interaction among specialists in the MDT is fundamental, particularly for pre-procedure patient evaluation and selection. While there is great excitement about the application of transcatheter valve therapies, most of these therapies will only be indicated for a small portion of the population for the immediate future. Proper decision-making and determination of best options for any given patient require an evaluation by the MDT. $^{21}$

On-site valve surgery is an essential component of any valve therapy program. The requirement for on-site valve surgery is based not only on the potential need for emergency or "back-up" surgery for percutaneous patients, but more importantly on the quality of patient evaluation and selection, decision-making, intra-procedure management, and post-procedure care and outcomes.

A cardiac surgeon and an interventional cardiologist must evaluate every case. The interplay between interventional cardiologists and cardiac surgeons represents only part of the benefit of the MDT. Additional critical contributions are provided by cardiac anesthesiology, imaging specialists in both cardiology and radiology, and by the many people beyond the physician members of the team. The MDT is led by a core group of physicians from interventional cardiology, cardiac surgery, cardiac anesthesiology, and intensive care and cardiac imaging departments, along with congenital heart disease specialists and surgeons. Depending on the institutional organization and the needs of the patient, vascular surgery and interventional radiology departments will also participate in the MDT in many situations. Additional team members include nurse practitioners from all of these fields, data/research coordinators, and a dedicated administrator.

The function of the MDT is essential in pre-procedure patient selection, intra-procedure management and problem solving, post-procedure management, postdischarge follow-up, and outcome studies. During procedures, emergencies or unanticipated needs may arise as a matter of course, even in the most straightforward situation; this is a familiar situation for proceduralists in any field. The rapid availability of the MDT support to help with decision-making or with therapy is essential. A clear definition of roles for the various specialties as well as effective communication, which may be different from that for conventional procedures, is critical for successful outcomes. A difficult course post-procedure is common in the high-risk patients who comprise a large part of the target population for both transcatheter and operative valve therapies. A team approach to problem solving in this setting is critical. Another important part of patient management is the familiarity 
that the intensive care unit and the monitored step-down floor staff have with the specific details of each form of valve therapy. After the post-procedure management phase, long-term follow-up for this select group of patients is also part of the MDT's responsibility. Post-approval registries will be required for many of the new transcatheter valve therapies, and therefore, a data collection/research unit within the MDT is another required component.

For sites with no prior trial experience in mitral, transcatheter therapies, background experience with related procedures is important. Surgical mitral procedures and trans-septal puncture procedures are essential background elements necessary for mitral therapy programs. For transcatheter procedures that do not directly involve the surgeon as a procedure operator, the role of the cardiac surgeon remains critically important. The surgeon has many roles and is often a patient advocate and/or referring physician, may be the primary operator and is a necessary scientific study participant in all of these device applications. The surgeon is familiar with established standards of care for application of transcatheter therapies and is frequently in charge of assessing high-risk patients for catheter-based therapy as an alternative to surgery. In a valve therapy program, patient assessment is a multidisciplinary undertaking.

Another mechanism for promoting a team approach that involves both surgeons and cardiologists is split or shared physician reimbursement for these procedures, which this writing group strongly endorses. This important principle will ensure that surgeons and cardiologists participate jointly in performing procedures and that each patient receives the best and most patient-centered treatment.

The MDT should meet formally as a group on a regular basis (aside from the usual "cath conference") to review all patients referred for procedures, the performance of recent procedures (to discuss both good and poor outcomes), and follow-ups of prior procedures.

\section{FUNCTION OF THE MULTIDISCIPLINARY TEAM}

Programmatic success depends on the ability of the MDT to function effectively in the best interest of a given patient. To do so, the MDT must work cohesively through the processes of patient selection, procedural planning, procedural conduct, periprocedural care, and longitudinal follow-up. Through each phase of this continuum, the individual skills of the MDT members should be brought to bear upon the process.

The procedural success of transcatheter valve therapies begins with patient selection. Given the complexity of the decision-making process surrounding these procedures, all MDT members must provide objective input and judgments from the outset of a patient evaluation. The patient selection process may be initiated by the use of regularly scheduled patient selection conferences attended by all MDT members. Such conferences are analogous to transplant patient selection committee meetings, and they provide a venue in which patient-specific data and imaging are formally presented and discussed by the MDT. The respective expertise of each discipline represented among MDT members may then be synthesized into a patientspecific recommendation. Each member of the heart team that evaluates the patient must record his/her opinion and enter it formally into the patient record.

Direct patient evaluation by cardiologists and cardiac surgeons may be accomplished jointly and, if possible, simultaneously in a venue such as a multi-disciplinary valve program clinic. Not only does such a clinic provide convenience for many patients, but it also provides an opportunity for cardiac surgeons and cardiologists to jointly examine and evaluate complex cases.

In so doing, the expertise and judgment of both disciplines may be woven into a patient-specific decision. The participation of anesthesiologists in these clinics may also be useful.

Following the decision that a given patient is an appropriate candidate for transcatheter mitral valve therapy, the procedure must then be carefully planned. Cardiac surgical teams are familiar with, and routinely use the concept of, "pre-procedure briefings," prior to complex cardiac surgical operations. This should be applied to structural procedures as well. In such briefings, all team members (surgeons, interventionalists, anesthesiologists, perfusionists, nurses, technicians, etc.) discuss the intended procedure, including the steps of the planned procedure, the specific tools and equipment needed (beyond those typically used), the possible complications that may arise during the course of the procedure, and the contingency plans that will be implemented should the unexpected occur. All members of the team can then initiate the planned procedure with a common understanding of its conduct and what will happen if the plan needs to change.

Adding the cardiologist and the catheterization team to this pre-procedure planning and MDT briefing is important for procedural success. During the procedure, emergency situations and unexpected needs may arise. The immediate availability of MDT physician support in emergency decision-making and therapy is essential. It is therefore important that the roles of the various specialties be clearly delineated during pre-procedure planning.

In many cases, the initial post-procedure care should be provided in an intensive care setting. A team approach to the care of these patients, and to problem solving, is important and should include physicians skilled in critical care medicine. Once inpatients are able to leave the intensive care environment, they should be attended by a unit specializing in the care of patients with cardiac diseases, and this unit should be equipped with telemetrymonitored beds. Again, a team approach is important for 
success. The team of physicians, nurses, occupational and physical therapists, and other members must have an understanding of the pathophysiology of mitral valve disease as well as the nuances of care for patients who have undergone cardiac surgery and interventional cardiology procedures.

The procedural success of transcatheter valve therapies, including the mitral valve, must be determined via longitudinal outcomes. Long-term follow-up of these patients is an important element of the MDT approach. Post-FDA approval registries will be required for most transcatheter valve therapies. Therefore, a long-term relationship between the patient and the MDT must be established, to undertake the needed alterations in medical therapy, serial echocardiographic imaging, and monitoring of devices. Likewise, changes in patient functional status, heart failure class, potential device-related complications, and other such conditions must be carefully tracked. A valve program clinic can provide a venue for this type of long-term follow-up.

The post-market surveillance of transcatheter valve devices will be an extremely important function of the MDT. Participation in device-specific registries can be challenging and requires an institutional infrastructure and commitment that includes experienced data managers with a background in cardiac disease, funding, office space, and computer resources. It requires a data coordinating/ clinical research unit with rigorous attention to detail, and the collection of accurate data as an integral part of the MDT.

\section{CRITERIA FOR ESTABLISHING A TRANSCATHETER VALVE PROGRAM AND MAINTENANCE OF COMPETENCE}

An important issue in the establishment of a transcatheter mitral valve program is the clinical or referral base to ensure an adequate number of patients to provide for the viability of a program. Table 1 details the important requirements for the establishment of a successful transcatheter mitral valve program.

The surgical program numbers in Table 1 were obtained by querying the STS database, which revealed that at the operative numbers noted, there would be approximately 256 sites in 46 states that would qualify.

Once chosen for participation as transcatheter mitral programs, either as existing programs or as new programs, in order to maintain ongoing approval for participation, sites will need to be monitored to ensure that they continue to satisfy both the volume and outcome criteria as described in Table 1.

Unlike the significant existing experience with PCI, where abundant data attest to the relationship between the volume of procedures and outcomes, there are little or no data on which to draw conclusions as to the volume-outcome relationship for transcatheter valve therapy. Therefore, the above recommendations are constructed to (1) ensure patient safety, (2) demonstrate that there is a commitment on the part of the institution to the structural heart disease program, and (3) use existing volume as a surrogate for an established valve program to ensure adequate patient volumes for the establishment of a sustainable transcatheter valve program. As experience grows and more data become available, these recommendations will undoubtedly be refined.

\section{TRANSCATHETER MITRAL VALVE REPAIR}

MR is a common lesion present in up to $24 \%$ of adults with valvular heart disease. ${ }^{21}$ It is clear from the literature that valve repair yields superior outcomes to replacement in patients with degenerative disease, although the benefits of repair over replacement in patients with functional MR due to ischemic heart disease or dilated cardiomyopathy are less clear. Due to a combination of the mitral valve's structural complexity, unique anatomic location, and wide variability of pathology, numerous surgical techniques have been developed over the past several decades to repair and replace this valve. It is therefore not surprising that several innovative concepts for transcatheter mitral valve therapy have been explored. These transcatheter approaches can be loosely grouped, based on the anatomic region targeted for intervention, eg, leaflet repairs, annular repairs, chordal repairs, and valve implants.

To date, the greatest clinical experience is with leaflet repairs, namely, percutaneous, edge-to-edge coaptation, in which the anterior and posterior leaflets of the mitral valve are approximated to create a double orifice mitral valve and restore coaptation. This approach is based on the surgical technique described by Alfieri et al. and has been used for a variety of pathologic MR disease states. ${ }^{22,23}$ By far the greatest transcatheter experience to date has been with the MitraClip (Abbott Vascular, Santa Clara, Calif), the clinical results of which were published in the EVEREST I and II trials and the continued access REALISM registry. ${ }^{23-25}$ Intraprocedural patient management requires the participation of the interventional cardiologist, echocardiographer, anesthesiologist, and supporting cardiac surgeon. Other transcatheter procedures focusing on leaflet modification (such as leaflet ablation and space occupation between leaflets) or annular reduction are in various stages of development and are not yet in clinical practice outside of clinical trials. ${ }^{26-29}$ It is likely that these procedures will require similar pre-procedural assessment, intra-procedural personnel and equipment, operator experience, and post-procedural assessment and care.

The pre-, intra-, and post-procedure evaluation of MR patients is arguably the most complex evaluation of the various valve lesions amenable to any form of transcatheter therapy. Success will therefore heavily depend on a 
multidisciplinary approach that includes the echocardiographer, clinical cardiologist, cardiac surgeon, and interventional cardiologist. Variations on other techniques for transcatheter mitral repair are under development and will be addressed in a future version of these recommendations.

The MitraClip is currently the only mitral valve procedure approved by the FDA. In regards to this procedure, the collaboration of the cardiothoracic surgeon and interventional cardiologist will span the pre-, intra-, and post-procedure care of the patient. The procedure itself is commonly performed by a single physician. This physician may be either an interventional cardiologist or a cardiothoracic surgeon; however, for some patients, the expertise of two physicians (either two interventional cardiologists, or an interventional cardiologist and a cardiothoracic surgeon) could be required. For future trans-catheter mitral valve replacement, as with TAVR, the cardiothoracic surgeon and interventional cardiologist are to be fully involved in all aspects of care: pre-operative assessment/patient selection, intraprocedural and post-procedural management and followup. Depending on the nature of subsequently approved devices, intraprocedural management may require the simultaneous involvement of an interventional cardiologist and a cardiovascular surgeon.

\section{NATIONAL REGISTRY}

FDA clearance of a novel valve repair or replacement prosthesis does not guarantee that the device will continue to demonstrate long-term efficacy equal to currently available options, or that it will be limited to the initially approved patient subsets. Post-market studies organized through individual institutions or multicenter study groups and registries managed by industry and professional societies are essential to ensuring continued short-term safety, and to determining long-term efficacy. Only with such data can we consider the application of new valve prostheses to a wider patient population outside the boundaries of the study groups examined during FDA trials. Centers that incorporate transcatheter-based therapies into their practice absolutely must participate in the TVTNCDR database. Early post-procedure morbidity and mortality analyses, while important for initial and continued implant safety assessment, are not sufficient to evaluate the efficacy of valve repair or replacement prostheses. Studies on long-term follow-up survival and, more importantly, structural valve degeneration, and the need for reintervention, are essential.

Transcatheter valve repair or replacement devices are unique in that an understanding not only of early risk, but also of long-term durability, is essential to determining the appropriate patient subgroups for these therapies. In our opinion, it is the responsibility of professional societies to ensure adequate long-term data monitoring and to provide oversight and guidance to industry on the expectations for continued monitoring beyond the FDA approval phase of device development and implementation. Individual centers are also responsible for critically evaluating their own experience, through local and regional quality improvement initiatives, and for participating in national databases and registries that facilitate continued safety and efficacy in the assessment of novel and as yet unproven therapeutic options.

\section{References}

1. http://www.cardiosource.org/Science-And-Quality/Practice-Guide-lines-and-Qua lity-Standards/Relationships-With-Industry-Policy.aspx.

2. Ruiz CE, Feldman TE, Hijazi ZM, Holmes DR Jr, Webb JG, Tuzcu EM, et al. Interventional fellowship in structural and congenital heart disease for adults: Core curriculum. Catheter Cardiovasc Interv. 2010;76:E90-105. J Am Coll Cardiol Interv. 2010;3:el-15.

3. Feldman T, Ruiz CE, Hijazi Z. The SCAI Structural Heart Disease Council: Toward addressing training, credentialing, and guidelines for structural heart DISEASE intervention. Catheter Cardiovasc Interv. 2010;76:E87-9.

4. Vassiliades TA Jr, Block PC, Cohn LH, et al. The clinical development of percutaneous heart valve technology: A position statement of the Society of Thoracic Surgeons (STS), the American Association for Thoracic Surgery (AATS), and the Society for Cardiovascular Angiography and Interventions (SCAI). J Thorac Cardiovasc Surg. 2005;129:970-6. J Am Coll Cardiol 2005;45:1554-60; Ann Thorac Surg. 2005;79:1812-8; Catheter Cardiovasc Interv. 2005;65:73-9.

5. Herrmann HC, Baxter S, Ruiz CE, Feldman TE, Hijazi Z. Results of the Society for Cardiac Angiography and Interventions survey of physicians and training directors on procedures for structural and valvular heart disease. Catheter Cardiovasc Interv. 2010;76:E106-10.

6. Cameron AC, Laskey W, Sheldon WC. SCAI ad hoc task force on ethics in invasive and interventional cardiology. Catheter Cardiovasc Interv. 2004;61:157-62.

7. Kouchoukos NT, et al. Guidelines for credentialing of practitioners to perform endovascular stent-grafting of the thoracic aorta. J Thorac Cardiovasc Surg. 2006;131:530-2.

8. Beller G, et al. 28th Bethesda Conference. Task Force 3: Guidelines for credentialling practicing physicians. J Am Coll Cardiol. 1997;29:1148-62.

9. Advisory Council for Cardiac Surgery, American College of Surgeons. Guidelines for standards in cardiac surgery. Bull Am Coll Surg. 1997;82:27-9.

10. Vahanian A, et al. Transcatheter valve implantation for patients with aortic stenosis: A position statement from the European Association of CardioThoracic surgery (EACTS) and the European Society of Cardiology (ESC), in collaboration with the European Association of Percutaneous Cardiovascular Interventions (EAPCI). Eur J Cardiothorac Surg. 2008;34:1-8.

11. Beller GA, Winters WL Jr, Carver JR, et al. Task force 3: Guidelines for credentialing practicing physicians. American College of Cardiology, 2000. Available at: http://www.acc.org. Accessed July 14, 2004.

12. Petersen ED, Coombs LP, DeLong ER, et al. Procedure volume as a marker of quality for CABG surgery. JAMA. 2004;291:195-201.

13. Crawford FA, Anderson RP, Clark RE, et al. Volume requirements for cardiac surgery credentialing: A critical examination of the ad hoc committee on cardiac surgery credentialing of the Society of Thoracic Surgeons. Ann Thorac Surg. 1996;61:12-6.

14. Bashankaev B, Baido S, Wexner SD. Review of available methods of simulation training to facilitate surgical education. Surg Endosc. 2011;25:28-35.

15. Hislop SJ, et al. Simulation case rehearsals for carotid artery stenting. Eur J Vasc Endovasc Surg. 2009;38:750-4.

16. Cacho F, Doblare M, Holzapfel GA. A procedure to simulate coronary artery bypass graft surgery. Med Biol Eng Comput. 2007;45:819-27.

17. Tedesco MM, et al. Simulation-based endovascular skills assessment: The future of credentialing. J Vasc Surg. 2008;47:1008-11.

18. Seymour NE, Gallagher AG, Roman SA, O'Brien MK, Bansal VK, Andersen DK, et al. Virtual reality improves operating room performance: Results of a randomized doubleblind study. Ann Surg. 2002;236:458-64.

19. Bashore TM, Balter S, Barac A, Byrne JG, Cavendish JJ, Chambers CE, et al. 2012 American College of Cardiology Foundation/Society for 
Cardiovascular Angiography and Interventions expert consensus document on cardiac catheterization laboratory standards update: A report of the American College of Cardiology Foundation Task Force on Expert Consensus documents developed in collaboration with the Society of Thoracic Surgeons and Society for Vascular Medicine. J Am Coll Cardiol. 2012;59:2221-305

20. Neily J, Mills PD, Young-Xu Y, Carney BT, West P, Berger DH, et al. Association between implementation of a medical team training program and surgical mortality. JAMA. 2010;304:1693-700.

21. Feldman T, Hijazi Z. Establishing a program in structural heart disease interventional therapies. In: Hijazi Z, Feldman T, Abdullah MH, Sievert H, eds. Transcatheter Closure of Atrial Septal Defects and Patent Foramen Ovale. Minneapolis: CardioText Publishing; 2010.

22. Alfieri O, Maisano F, De Bonis M, et al. The double-orifice technique in mitral valve repair: A simple solution for complex problems. J Thorac Cardiovasc Surg. 2001;122:674-81.

23. Feldman T, Kar S, Rinaldi M, et al. Percutaneous mitral repair with the MitraClip System. Safety and midterm durability in the initial EVEREST (Endovascular Valve Edge-to-Edge REpair Study) cohort. J Am Coll Cardiol. 2009;54:686-94.
24. Feldman T, Foster E, Glower DG, et al. Percutaneous repair or surgery for mitral regurgitation. $N$ Engl J Med. 2011;364:1395-406.

25. George JC, Varghese V, Dangas G, Feldman TE. Percutaneous mitral valve repair: lessons from the EVEREST II (Endovascular Valve Edge-to-Edge REpair Study) and beyond. JACC Cardiovasc Interv. 2011;4:825-7.

26. Siminiak T, Hoppe UC, Schofer J, et al. Effectiveness and safety of percutaneous coronary sinus-based mitral valve repair in patients with dilated cardiomyopathy (from the AMADEUS trial). Am J Cardiol. 2009;104: 565-70.

27. Schofer J, Siminiak T, Haude M, et al. Percutaneous mitral annuloplasty for functional mitral regurgitation: Results of the CARILLON Mitral Annuloplasty Device European Union Study. Circulation. 2009;120:326-33.

28. Harnek J, Webb JG, Kuck KH, et al. Transcatheter implantation of the MONARC coronary sinus device for mitral regurgitation 1-year results from the EVOLUTION phase I study (Clinical Evaluation of the Edwards Lifesciences Percutaneous Mitral Annuloplasty System for the Treatment of Mitral Regurgitation). J Am Coll Cardiol Interv. 2011;4:115-22.

29. Sack S, Kahlert P, Bilodeau L, et al. Percutaneous transvenous mitral annuloplasty: Initial human experience with a novel coronary sinus implant device. Circ Cardiovasc Interv. 2009;2:277-84. 
APPENDIX 1. Author relationships with industry and other entities (relevant)—SCAI/AATS/ACC/STS operator \& institutional requirements for transcatheter valve repair and replacement, part II-mitral valve

\begin{tabular}{|c|c|c|c|c|c|c|}
\hline Committee member & Consultant & $\begin{array}{l}\text { Speaker's } \\
\text { bureau }\end{array}$ & $\begin{array}{c}\text { Ownership/ } \\
\text { partnership/ } \\
\text { principal }\end{array}$ & Personal research & $\begin{array}{c}\text { Institutional, } \\
\text { organizational } \\
\text { or other financial } \\
\text { benefit }\end{array}$ & $\begin{array}{l}\text { Expert } \\
\text { witness }\end{array}$ \\
\hline Ziyad M. Hijazi, MD & Venus Medtech & None & $\begin{array}{l}\text { Colibri Heart } \\
\text { Valve* }\end{array}$ & None & PICS Foundation* & None \\
\hline Carlos E. Ruiz, MD & None & None & None & None & None & None \\
\hline Evan Zahn, MD & Medtronic* & None & None & None & None & None \\
\hline Joaquin E. Cigarroa, MD & None & None & None & None & None & None \\
\hline Gabriel S. Aldea, MD & None & None & None & None & None & None \\
\hline Emile A. Bacha, MD & None & None & None & None & None & None \\
\hline Joseph Bavaria, MD & St. Jude Medical & None & None & $\begin{array}{l}\text { Edwards Lifesciences* } \\
\text { Medtronic* }\end{array}$ & None & None \\
\hline R. Morton Bolman III, MD & None & None & None & None & None & None \\
\hline Duke E. Cameron, MD & None & None & None & None & None & None \\
\hline Larry S. Dean, MD & None & None & None & Edwards Lifesciences $\dagger$ & None & None \\
\hline Ted Feldman, MD & $\begin{array}{l}\text { WL Gore, Edwards } \\
\text { Lifesciences, Boston } \\
\text { Scientific, Abbott }\end{array}$ & None & None & $\begin{array}{l}\text { WL Gore* } \\
\text { Edwards Lifesciences* } \\
\text { Abbott* } \\
\text { Boston Scientific* }\end{array}$ & None & None \\
\hline David Fullerton, MD & None & None & None & None & None & None \\
\hline Eric Horlick, MDCM & $\begin{array}{l}\text { St. Jude Medical } \dagger \\
\text { Medtronic } \\
\text { WL Gore } \\
\text { Edwards Lifesciences }\end{array}$ & None & None & None & None & None \\
\hline Michael J. Mack, MD & None & None & None & Edwards Lifesciences* & None & None \\
\hline D. Craig Miller, MD & $\begin{array}{l}\text { Abbott } \\
\text { Medtronic }\end{array}$ & None & None & Edwards Lifesciences* & None & None \\
\hline Marc R. Moon, MD & None & None & None & None & None & None \\
\hline Alfredo Trento, MD & None & None & None & None & None & None \\
\hline Carl L. Tommaso, MD & None & None & None & None & None & None \\
\hline Debabrata Mukherjee, MD & None & None & None & None & None & None \\
\hline Bonnie Weiner, MD & Cersys/Surpass & None & None & None & None & None \\
\hline
\end{tabular}

This table represents relevant healthcare relationships of committee members with industry and other entities that were reported by authors, at the time this document was under development. The table does not necessarily reflect relationships with industry at the time of publication. A person is deemed to have a significant interest in a business if the interest represents ownership of $\geq 5 \%$ of the voting stock or share of the business entity, or ownership of $\geq \$ 10,000$ of the fair market value of the business entity; or if funds received by the person from the business entity exceed 5\% of the person's gross income for the previous year. Relationships that exist with no financial benefit are also included for the purpose of transparency. Relationships in this table are modest unless otherwise noted. Please refer to http://www.cardiosource.org/Science-And-Quality/PracticeGuidelines-and-Quality-Standards/Relationships-With-Industry-Policy.aspx for definitions of disclosure categories or additional information about the ACC Disclosure Policy for Writing Committees. *No financial benefit. †Significant relationship. 
Author relationships with industry and other entities (comprehensive)_SCAI/AATS/ACCF/STS operator \& institutional requirements for transcatheter valve repair and replacement, part II-mitral valve

\begin{tabular}{|c|c|c|c|c|c|c|}
\hline Committee member & Consultant & $\begin{array}{c}\text { Speaker's } \\
\text { bureau }\end{array}$ & $\begin{array}{l}\text { Ownership/ } \\
\text { partnership/ } \\
\text { principal }\end{array}$ & Personal research & $\begin{array}{c}\text { Institutional, } \\
\text { organizational or } \\
\text { other financial } \\
\text { benefit }\end{array}$ & $\begin{array}{l}\text { Expert } \\
\text { witness }\end{array}$ \\
\hline Ziyad M. Hijazi, MD & Occlutech* NuMED Inc,* & None & Colibri Heart Valve $\dagger$ & None & PICS Foundation $\dagger$ & None \\
\hline Carlos E. Ruiz, MD & None & None & None & None & None & None \\
\hline Evan Zahn, MD & Medtronic $\dagger$ & None & None & None & None & None \\
\hline Joaquin E. Cigarroa, MD & None & None & None & None & None & 2010,2011 \\
\hline Gabriel S. Aldea, MD & None & None & None & None & None & None \\
\hline Emile A. Bacha, MD & Cormatrix & None & None & None & None & None \\
\hline Joseph Bavaria, MD & St. Jude Medical & None & None & $\begin{array}{l}\text { Sorin } \dagger \\
\text { Edwards Lifescience } \dagger \\
\text { Medtronic } \dagger\end{array}$ & None & 2013 \\
\hline R. Morton Bolman III, MD & None & None & None & Glaxo-Smith-Kline $\dagger$ & None & None \\
\hline Duke E. Cameron, MD & None & None & None & None & None & None \\
\hline Larry S. Dean, MD & Phillips Medical & $\begin{array}{l}\text { Daiichi } \\
\text { Sankyo } \\
\text { Lilly }\end{array}$ & $\begin{array}{c}\text { Emageon (stock } \\
\text { ownership) }\end{array}$ & Edwards Lifesciences* & None & None \\
\hline Ted Feldman, MD & $\begin{array}{l}\text { WL Gore } \\
\text { Edwards Lifesciences } \\
\text { Abbott } \\
\text { Boston Scientific }\end{array}$ & None & None & $\begin{array}{l}\text { WL Gore } \dagger \\
\text { Edwards Lifesciences } \dagger \\
\text { Abbott } \dagger \\
\text { Boston Scientific } \\
\quad \text { Corporation } \dagger\end{array}$ & None & None \\
\hline David Fullerton, MD & None & None & None & None & None & None \\
\hline Eric Horlick, MDCM & $\begin{array}{l}\text { St. Jude Medical* } \\
\text { Medtronic } \\
\text { Gore } \\
\text { Edwards Lifesciences }\end{array}$ & None & None & $\begin{array}{l}\text { Gore } \dagger \\
\text { St. Jude Medical } \\
\text { Medtronic } \dagger\end{array}$ & None & 2004,2012 \\
\hline Michael J. Mack, MD & None & None & None & Edwards Lifesciences $\dagger$ & None & None \\
\hline D. Craig Miller, MD & $\begin{array}{l}\text { GenTAC/HHLBI under } \\
\text { contract to RTI Abbott } \\
\text { Vascular MitraClip } \\
\text { Medtronic } \\
\text { PARTNER U.S. }\end{array}$ & None & None & Edwards Lifesciences $\dagger$ & None & None \\
\hline Marc R. Moon, MD & None & None & None & Carbomedics $\dagger$ & None & 2012 \\
\hline Alfredo Trento, MD & None & None & None & None & None & None \\
\hline Carl L. Tommaso, MD & & None & None & None & $\mathrm{SCAI} \dagger$ & 2004,2006 \\
\hline Debabrata Mukherjee, MD & None & None & None & None & None & None \\
\hline Bonnie Weiner, MD & $\begin{array}{l}\text { Stryker } \\
\text { Atricure } \\
\text { Atheromed }\end{array}$ & None & $\begin{array}{l}\text { Imaging Core } \\
\text { Lab Services* }\end{array}$ & None & None & None \\
\hline
\end{tabular}

This table represents all healthcare relationships of committee members with industry and other entities that were reported by authors, including those not deemed to be relevant to this document, at the time this document was under development. The table does not necessarily reflect relationships with industry at the time of publication. A person is deemed to have a significant interest in a business if the interest represents ownership of $\geq 5 \%$ of the voting stock or share of the business entity, or ownership of $\geq \$ 10,000$ of the fair market value of the business entity; or if funds received by the person from the business entity exceed 5\% of the person's gross income for the previous year. Relationships that exist with no financial benefit are also included for the purpose of transparency. Relationships in this table are modest unless otherwise noted. Please refer to www.car-diosource. org/Science-And-Quality/Practice-Guidelines-and-Quality-Standards/Relationships-With-Industry-Policy.aspx for definitions of disclosure categories or additional information about the ACC Disclosure Policy for Writing Committees. *Significant relationship. $†$ No financial benefit. 
APPENDIX 2. Peer reviewer relationships with industry and other entities (relevant)—SCAI/AATS/ACCF/STS operator \& institutional requirements for transcatheter valve repair and replacement, part II-mitral valve

\begin{tabular}{|c|c|c|c|c|c|c|c|}
\hline Peer reviewer & Employment & Consultant & $\begin{array}{c}\text { Speaker's } \\
\text { bureau }\end{array}$ & $\begin{array}{c}\text { Ownership/ } \\
\text { partnership/ } \\
\text { principal }\end{array}$ & $\begin{array}{l}\text { Personal } \\
\text { research }\end{array}$ & $\begin{array}{c}\text { Institutional, } \\
\text { organizational, } \\
\text { or other financial } \\
\text { benefit }\end{array}$ & Expert witness \\
\hline Vinay Badhwar & UPMC Presbyterian & None & None & None & None & $\begin{array}{l}\text { - Abbot } \\
\text { Cardiovascular } \\
\text { - Edwards } \\
\text { Lifesciences }\end{array}$ & None \\
\hline Anthony A. Bavry & $\begin{array}{l}\text { Malcom Randall } \\
\text { Veterans } \\
\text { Administration } \\
\text { Medical Center, } \\
\text { University of } \\
\text { Florida- } \\
\text { Interventional } \\
\text { Cardiologist, } \\
\text { Assistant Professor }\end{array}$ & None & None & None & None & None & None \\
\hline $\begin{array}{c}\text { Emmanouil S. } \\
\text { Brilakis }\end{array}$ & $\begin{array}{l}\text { VA North Texas } \\
\text { Healthcare System, } \\
\text { UT Southwestern } \\
\text { Medical School- } \\
\text { Director Cardiac } \\
\text { Catheterization } \\
\text { Laboratory }\end{array}$ & $\begin{array}{l}\text { - Abbot } \\
\text { Vascular } \\
\text { - St. Jude } \\
\text { Medical }\end{array}$ & None & None & None & $\begin{array}{l}\text { Abbot Vascular* } \\
\text { Medtronic } \dagger\end{array}$ & $\begin{array}{l}\text { 2012, Defendant- } \\
\text { Expert testimony } \\
\text { of case of left main } \\
\text { disease } \\
\text { 2011, Defendant- } \\
\text { Review of case of } \\
\text { left main disease }\end{array}$ \\
\hline John G. Byrne & $\begin{array}{l}\text { Harvard Medical } \\
\text { School, Brigham } \\
\text { and Women's } \\
\text { Hospital- } \\
\text { Lawrence H. Cohn } \\
\text { Professor of Surgery, } \\
\text { Chief, Division of } \\
\text { Cardiac Surgery, } \\
\text { Surgical Director } \\
\text { BWH Heart and } \\
\text { Vascular Center }\end{array}$ & None & None & None & None & None & None \\
\hline David R. Holmes, Jr & $\begin{array}{l}\text { Mayo Clinic- } \\
\text { Consultant, } \\
\text { Cardiovascular } \\
\text { Disease }\end{array}$ & None & None & None & None & Boston Scientific & None \\
\hline Clifford Kavinsky & $\begin{array}{l}\text { Rush Presbyterian St. } \\
\text { Luke's Medical } \\
\text { Center }\end{array}$ & None & None & None & None & None & None \\
\hline Saibal Kar & $\begin{array}{l}\text { Cedars-Sainai- } \\
\text { Director, } \\
\text { Cardiovascular } \\
\text { Intervention Center } \\
\text { Research }\end{array}$ & $\begin{array}{l}\text { Abbott } \\
\text { Vascular } \dagger\end{array}$ & Medtronic & None & $\begin{array}{l}\text { Abbott Vascular } \dagger \\
\text { St. Jude Medical } \dagger\end{array}$ & None & None \\
\hline Hersh Maniar & & None & None & None & None & None & None \\
\hline Issam D. Moussa & $\begin{array}{l}\text { Mayo Clinic- } \\
\text { Professor of } \\
\text { Medicine; Chair, } \\
\text { Division of }\end{array}$ & None & None & None & None & None & None \\
\hline
\end{tabular}




\begin{tabular}{|c|c|c|c|c|c|c|c|}
\hline Peer reviewer & Employment & Consultant & $\begin{array}{c}\text { Speaker's } \\
\text { bureau }\end{array}$ & $\begin{array}{c}\text { Ownership/ } \\
\text { partnership/ } \\
\text { principal }\end{array}$ & $\begin{array}{l}\text { Personal } \\
\text { research }\end{array}$ & $\begin{array}{c}\text { Institutional, } \\
\text { organizational, } \\
\text { or other financial } \\
\text { benefit }\end{array}$ & Expert witness \\
\hline & $\begin{array}{l}\text { Cardiovascular } \\
\text { Disease }\end{array}$ & & & & & & \\
\hline J. Brent Muhlestein & $\begin{array}{l}\text { Intermountain Medical } \\
\text { Center, Cardiology } \\
\text { Dept. Level 6- } \\
\text { Professor of } \\
\text { Medicine }\end{array}$ & None & None & None & None & None & $\begin{array}{l}\text { 2011, Defendant- } \\
\text { Cardiac } \\
\text { Catheterization }\end{array}$ \\
\hline Rick A. Nishimura & $\begin{array}{l}\text { Mayo Clinic, Division } \\
\text { of Cardiovascular } \\
\text { Disease-Judd and } \\
\text { Mary Morris } \\
\text { Leighton Professor } \\
\text { of Medicine }\end{array}$ & None & None & None & None & None & None \\
\hline Robert N. Piana & $\begin{array}{l}\text { Vanderbilt University } \\
\text { Medical Center- } \\
\text { Professor of } \\
\text { Medicine } \\
\text { (Cardiology) }\end{array}$ & None & None & None & None & None & $\begin{array}{l}\text { - 2012, Third Party- } \\
\text { Quality Review } \\
\text { - 2012, Defendant- } \\
\text { Interventional } \\
\text { Cardiology } \\
\text { - 2011, Defendant- } \\
\text { Coronary Artery } \\
\text { Disease } \\
\text { Management } \\
\text { 2011, Defendant- } \\
\text { Coronary Artery } \\
\text { Disease } \\
\text { Management } \\
\text { 2011, Defendant- } \\
\text { Interventional } \\
\text { Cardiology }\end{array}$ \\
\hline \multirow[t]{2}{*}{ Joseph F. Sabik } & $\begin{array}{l}\text { Cleveland Clinic- } \\
\text { Professor of Surgery } \\
\text { and Chairman of the }\end{array}$ & $\begin{array}{l}\text { - Edwards } \\
\text { Lifesciences } \\
\text { - Medtronic }\end{array}$ & None & None & $\begin{array}{l}\text { - Abbott } \\
\text { Vascular } \\
\text { - Edwards } \\
\text { Lifesciences* } \\
\text { - St. Jude } \\
\text { Medical* }\end{array}$ & None & None \\
\hline & $\begin{array}{l}\text { Department of } \\
\text { Thoracic and } \\
\text { Cardiovascular } \\
\text { Surgery }\end{array}$ & & & & & & \\
\hline Vinod H. Thourani & $\begin{array}{l}\text { Emory University } \\
\text { School of } \\
\text { Medicine- } \\
\text { Associate Professor } \\
\text { of Surgery }\end{array}$ & $\begin{array}{l}\text { - Edwards } \\
\text { Lifesciences } \\
\text { - Sorin } \\
\text { - St. Jude } \\
\text { Medical* }^{*}\end{array}$ & None & None & None & None & None \\
\hline $\begin{array}{l}\text { Edward R. Tuohy, } \\
\text { IV }\end{array}$ & $\begin{array}{l}\text { Cardiac Specialists, } \\
\text { P.C.-Interventional } \\
\text { Cardiologist }\end{array}$ & None & None & None & None & None & None \\
\hline
\end{tabular}




\begin{tabular}{|c|c|c|c|c|c|c|c|}
\hline Peer reviewer & Employment & Consultant & $\begin{array}{c}\text { Speaker's } \\
\text { bureau }\end{array}$ & $\begin{array}{c}\text { Ownership/ } \\
\text { partnership/ } \\
\text { principal }\end{array}$ & $\begin{array}{l}\text { Personal } \\
\text { research }\end{array}$ & $\begin{array}{c}\text { Institutional, } \\
\text { organizational, } \\
\text { or other financial } \\
\text { benefit }\end{array}$ & Expert witness \\
\hline James S. Tweddell & $\begin{array}{l}\text { Medical College of } \\
\text { Wisconsin, } \\
\text { Children's Hospital } \\
\text { of Wisconsin- } \\
\text { Professor of Surgery } \\
\text { and Pediatrics, The } \\
\text { S. Bert Litwin Chair } \\
\text { of Cardiothoracic } \\
\text { Surgery }\end{array}$ & None & None & None & None & None & None \\
\hline Howard T. Walpole & $\begin{array}{l}\text { Okyanos Heart } \\
\text { Institute-Chief } \\
\text { Medical Officer }\end{array}$ & None & None & None & None & None & None \\
\hline \multicolumn{8}{|c|}{$\begin{array}{l}\text { This table represents the relationships of reviewers with industry and other entities that were disclosed at the time of peer review and determined to be relevant to this document. It } \\
\text { does not necessarily reflect relationships with industry at the time of publication. A person is deemed to have a significant interest in a business if the interest represents ownership } \\
\text { of } \geq 5 \% \text { of the voting stock or share of the business entity, or ownership of } \geq \$ 10,000 \text { of the fair market value of the business entity; or if funds received by the person from the } \\
\text { business entity exceed } 5 \% \text { of the person's gross income for the previous year. A relationship is considered to be modest if it is less than significant under the preceding definition. } \\
\text { Relationships that exist with no financial benefit are also included for the purpose of transparency. Relationships in this table are modest unless otherwise noted. Names are listed } \\
\text { in alphabetical order within each category of review. Please refer to http://www.cardiosource.org/Science-And-Quality/Practice-Guidelines-and-Quality-Standards/ } \\
\text { Relationships-With-Industry-Policy.aspx for definitions of disclosure categories or additional information about the ACC Disclosure Policy for Writing Committees. According } \\
\text { to the ACC, a person has a relevant relationship IF: (a) The relationship or interest relates to the same or similar subject matter, intellectual property or asset, topic, or issue } \\
\text { addressed in the document; or (b) The company/entity (with whom the relationship exists) makes a drug, drug class, or device addressed in the document, or makes a competing } \\
\text { drug or device addressed in the document; or (c) The person or a member of the person's household, has a reasonable potential for financial, professional or other personal gain or } \\
\text { loss as a result of the issues/content addressed in the document. *Significant relationship. †No financial benefit. }\end{array}$} \\
\hline
\end{tabular}

